\title{
Increased methanation activity through passivation of the silica support
}

Karol Furman ${ }^{\mathrm{a}}$, David Baudouin ${ }^{\mathrm{a}}$, Tigran Margossian ${ }^{\mathrm{a}}$, Kaiwalya D. Sabnis ${ }^{\mathrm{b}}$, Yanran

Cui $^{\mathrm{b}}$, Fabio H. Ribeiro ${ }^{\mathrm{b}}$, Christophe Copéret, ${ }^{\mathrm{a},}$

${ }^{a}$ ETH Zürich, Department of Chemistry and Applied Biosciences, Vladimir Prelog Weg 2, 8093 Zürich (Switzerland)

${ }^{b}$ Purdue University, School of Chemical Engineering, Forney Hall of Chemical Engineering, 480 Stadium Mall Drive, West Lafayette, N 47907-2100 (United States of America)

*Corresponding author: Phone: +41-44-633 9394

E-mail address: ccoperet@inorg.chem.ethz.ch 


\begin{abstract}
$\underline{\text { Abstract }}$
Improvement of the catalytic performance of supported nanoparticles (NP) is an intense area or research, which involves modification of many different parameters on a nanoparticle (such as variation of particle size), support (e.g. its reducibility) and metalsupport interactions. Here, we focus on the latter and show that the introduction of passivating groups (-OSi(Me $)_{2} \mathbf{R}$ with $\mathbf{R}=\mathbf{M e}$ or $\left.\mathbf{B u}\right)$ at the interface between the support surface (silica) and RuNPs increases the rate of the reaction on RuNPs (per mole of surface $\mathrm{Ru}$ atoms) by a factor 5-6 compared to silica-supported RuNPs, whose surface is exposed to silanols. Chemisorption, IR spectroscopy and temperature programmed desorption tests suggest that the rate increase likely originates from the difference in interaction between $\mathrm{CO}$ and RuNPs, which is influenced by the modification of the support surface functionality. It is also possible that the change in catalyst activity could be due to a modified electronic state of nanoparticles and/or their morphology.
\end{abstract}

\title{
$\underline{\text { Keywords }}$
}

Ruthenium nanoparticles, passivated silica, metal/support interaction, methanation, $\mathrm{CO}$ adsorption 


\section{$\underline{\text { 1. Introduction }}$}

The prospective global energy challenges arising up from continously increasing worldwide energy consumption creates a demand for the development of alternative energy sources such as solar, wind or nuclear [1-3]. However, the intermittent nature of the energy production and demand, as well as the unequal geographical source distribution, requires the development of efficient technologies to store energy and convert its excess into energy carriers. In this respect, the production of chemicals/fuels such as methanol, syngas or $\mathrm{CH}_{4}$ is of great interest [4,5]. Supported metal nanoparticles (NPs) are commonly used to catalyse the formation of these chemicals, and correspond to one of the largest classes of heterogeneous catalysts [6-9]. Numerous parameters influence the performances of such catalysts, such as the size and the distribution of the metallic nanoparticles [10], but also their interaction with the support surface [11-14]. Similar to what has been found for supported single-site catalysts (e.g. Ti- and Ta-based olefin epoxidation catalysts) [15-17], modification of the support by introducing passivating trimethylsilyl group can also improve the performances of supported metal NPs [18-22]. For instance, 2-nm Au nanoparticles (AuNPs) supported on passivated silica (silica covered with $-\mathrm{OSiMe}_{3}$ groups) display much higher activity in the aerobic epoxidation of stilbene $\left(0.12\right.$ mole. $\left.(\mathrm{g} \text { of } \mathrm{Au})^{-1} \cdot \mathrm{h}^{-1}\right)$ than the corresponding Au supported on standard oxide supports, including the most performant titania support $\left(0.023\right.$ mole. $\left.(\mathrm{g} \text { of } \mathrm{Au})^{-1} \cdot \mathrm{h}^{-1}\right)$ [23]. In addition, AuNPs on passivated silica catalyze the preferential oxidation of $\mathrm{CO}$ by $\mathrm{O}_{2}$ only when $\mathrm{H}_{2}$ is present, in contrast to the corresponding AuNPs supported on normal silica. These data clearly point out the importance of the so-called metal - support or nanoparticle - interface interaction, which here refers most likely to the presence or not of surface $\mathrm{Si}-\mathrm{OH}$. In line with the above discussion, we decided to explore the effect of passivating groups $\left(-\mathrm{OSi}(\mathrm{Me})_{2} \mathbf{R}\right.$; with $\mathbf{R}=\mathbf{M e}$ or $\left.\mathbf{B u}\right)$ at the surface of silica, in place of silanols, on the reactivity of supported metal nanoparticles towards Water Gas Shift (WGS) and methanation reactions (eq. 1 and 2, respectively).

$$
\begin{aligned}
& \mathrm{CO}+\mathrm{H}_{2} \mathrm{O} \leftrightarrows \mathrm{CO}_{2}+\mathrm{H}_{2} \\
& \mathrm{CO}+3 \mathrm{H}_{2} \leftrightarrows \mathrm{CH}_{4}+\mathrm{H}_{2} \mathrm{O}
\end{aligned}
$$


Here, we describe the synthesis of supported $\mathrm{Ru}$ nanoparticles (RuNPs) on passivated silica and show that the modification of the metal - support interaction (interface between the nanoparticle and the support) by introducing trialkylsilyl group on the support increases the rates of methanation through the modification of the adsorption properties of the metallic particles.

\section{Experimental}

2.1. General procedure. All experiments were carried out under dry and oxygen free Ar using either standard Schlenk or glove-box techniques for organometallic synthesis. For the syntheses and the treatments of RuNPs, reactions were carried out using high vacuum lines $\left(10^{-5} \mathrm{mbar}\right.$ ) and glove-box techniques. Silica (Aerosil Degussa, $200 \mathrm{~m}^{2} / \mathrm{g}$ ) was compacted with distilled water, calcined at $500{ }^{\circ} \mathrm{C}$ under air for $2 \mathrm{~h}$ and treated under vacuum $\left(10^{-5} \mathrm{mbar}\right)$ at $500{ }^{\circ} \mathrm{C}$ for $12 \mathrm{~h}$ and then at $700{ }^{\circ} \mathrm{C}$ for $4 \mathrm{~h}\left(\mathrm{SiO}_{2-700}\right)$. THF was distilled from sodium under $\mathrm{Ar}$ (benzophenone used as an indicator of dryness). $\mathrm{H}_{2}$ were purified over R3-11 BASF catalyst / MS 4 A prior to use.

2.2. WGS/methanation kinetic study. Supported RuNPs were loaded into a Plug Flow Reactor (PFR) and reduced in pure $\mathrm{H}_{2}(50 \mathrm{sccm})$ at $400^{\circ} \mathrm{C}\left(5^{\circ} \mathrm{C} \cdot \mathrm{min}^{-1}\right)$ for $5 \mathrm{~h}$, followed by a pretreatment at the standard WGS/methanation conditions $\left(7 \% \mathrm{CO}, 22 \% \mathrm{H}_{2} \mathrm{O}, 8.5 \%\right.$ $\mathrm{CO}_{2}, 37.5 \% \mathrm{H}_{2}$, and balance $\mathrm{Ar}$ ) with a flow rate of $75.4 \mathrm{sccm}$ at $300^{\circ} \mathrm{C}$ for $20 \mathrm{~h}$. After this pre-treatment, the temperature was lowered to reach conversion to be less than $10 \%$ in order to determine WGS/methanation rates and reaction orders under kinetic conditions $\left(275^{\circ} \mathrm{C}\right.$ for $\mathrm{Ru} / \mathrm{SiO}_{2}-\mathrm{OH}$, and to $260^{\circ} \mathrm{C}$ for $\mathrm{RuNPs}$ supported on passivated silica). Rate of the methanation reaction was calculated per mole of $\mathrm{Ru}$ surface atoms by taking into account the dispersion of supported RuNPs calculated from TEM study; 
Reaction orders with respect to $\mathrm{H}_{2}, \mathrm{CO}, \mathrm{H}_{2} \mathrm{O}$ and $\mathrm{CO}_{2}$ were studied by varying one gas concentration at the time. Apparent activation energy $\left(\mathrm{E}_{\text {app }}\right)$ was measured by changing the temperature within a range of $40^{\circ} \mathrm{C}$.

\section{Results and discussion.}

Passivated silica $\left(\mathrm{SiO}_{2}-\mathrm{OSi}(\mathrm{Me})_{2} \mathbf{R}\right)$ was prepared by the reaction of silica partially dehydroxylated at $700{ }^{\circ} \mathrm{C}\left(\mathrm{SiO}_{2-700}\right)$ [24] with different alkyldimethylchlorosilanes $\left(\mathbf{R}(\mathrm{Me})_{2} \mathrm{SiCl}\right.$ with $\mathbf{R}=\mathbf{M e}$ or $\left.\mathbf{B u}\right)$ in the presence of pyridine (Scheme S1, Figure S1) [25]. Then, the supported $\mathrm{Ru}$ nanoparticles $\left(\mathrm{Ru} / \mathrm{SiO}_{2}-\mathrm{OSi}(\mathrm{Me})_{2} \mathbf{R}\right)$ were obtained by impregnation of a THF solution of Ruthenium(1,5-cyclooctadiene)(1,3,5-cyclooctatriene), $[\mathrm{Ru}(\mathrm{COD})(\mathrm{COT})]$, targetting a final loading of $1 \mathrm{wt}$ \% $\mathrm{Ru}$, followed by a thermal treatment in a flow of $\mathrm{H}_{2}\left(300^{\circ} \mathrm{C}, 6 \mathrm{~h}\right)$ (Figure 1).

$\mathrm{R}=\mathrm{Me}, \mathrm{Bu}$
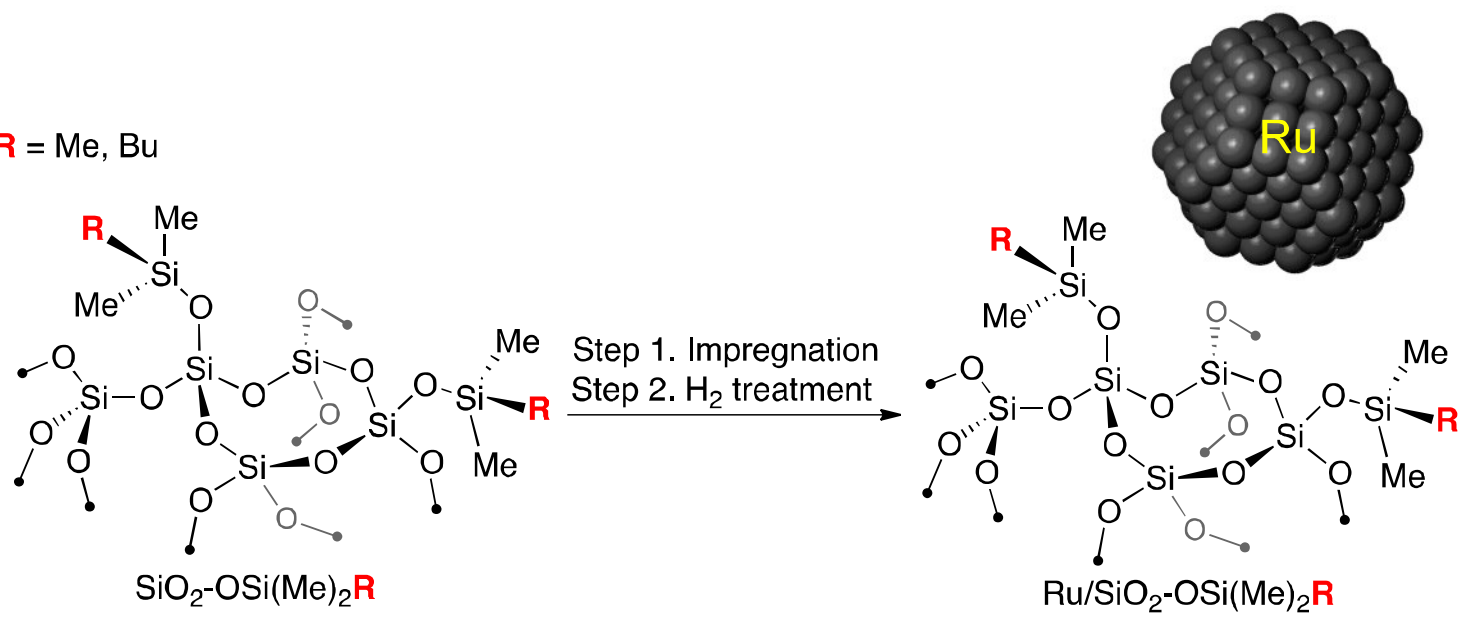

Figure 1. Synthesis of RuNPs on passivated silica; Step 1: Impregnation of the THF solution of $[\mathrm{Ru}(\mathrm{COD})(\mathrm{COT})]$; Step 2: Treatment under $\mathrm{H}_{2}\left(1 \mathrm{bar}, 38 \mathrm{~mL} \cdot \mathrm{min}^{-1}\right), 300^{\circ} \mathrm{C}$ $\left(0.5^{\circ} \mathrm{C} \cdot \mathrm{min}^{-1}\right), 6 \mathrm{~h}$.

During passivation, all silanols $(-\mathrm{OH})$ of $\mathrm{SiO}_{2-700}$ were converted into $\left(-\mathrm{OSi}(\mathrm{Me})_{2} \mathbf{R}\right)$ functionalities as evidenced by IR spectroscopy (Figure S1). During the treatment at 300 ${ }^{\circ} \mathrm{C}$ under $\mathrm{H}_{2}$, impregnated $[\mathrm{Ru}(\mathrm{COD})(\mathrm{COT})]$ decomposed, and the production of methane 
was evidenced as the result of the hydrogenolysis of the ligand attached to $\mathrm{Ru}$, namely cyclooctadiene and cyclooctatriene. This hydrogenolysis step took place without affecting the surface organosilane functionalities as evidenced by IR spectroscopy (Figure S3-S5). High-angle annular dark-field scanning transmission electron microscopy (HAADF-STEM) of RuNPs, which were exposed to ambient air prior microscopy study (Figure 2) corresponds to $\mathrm{RuO}_{2}$ nanoparticles (as evidenced by XPS; Figure S9-S11), whose mean size diameters are $1.5 \pm 0.3,1.5 \pm 0.2$ and $1.6 \pm 0.3$ for $\mathrm{Ru} / \mathrm{SiO}_{2^{-}}$ $\mathrm{OSi}(\mathrm{Me})_{2} \mathrm{Me}, \mathrm{Ru} / \mathrm{SiO}_{2}-\mathrm{OSi}(\mathrm{Me})_{2} \mathrm{Bu}$ and $\mathrm{Ru} / \mathrm{SiO}_{2}-\mathrm{OH}$, respectively. Correcting for the difference of molar volume ratio between $\mathrm{RuO}_{2}$ and $\mathrm{Ru}(0)$ (2.35), the calculated mean diameter of $\mathrm{Ru}(0)$ nanoparticles is thus $1.3 \pm 0.3,1.3 \pm 0.2$ and $1.4 \pm 0.3 \mathrm{~nm}$ for $\mathrm{Ru} / \mathrm{SiO}_{2}-$

$\mathrm{OSi}(\mathrm{Me})_{2} \mathrm{Me}, \mathrm{Ru} / \mathrm{SiO}_{2}-\mathrm{OSi}(\mathrm{Me})_{2} \mathbf{B u}$ and $\mathrm{Ru} / \mathrm{SiO}_{2}-\mathrm{OH}$ (Table 1.) Transmission electron microscopy (TEM) images of RuNPs exposed to ambient air prior microscopy study are presented in Figure S6.

Table 1. Particle size and metal dispersion of as-synthesized supported RuNPs (1 wt.\% Ru) according to HAADF-STEM.

$\begin{array}{cccc}\text { Materials } & \mathrm{Ru}_{\mathrm{SiO}}-\mathrm{OSi}(\mathrm{Me})_{2} \mathrm{Me} & \mathrm{Ru} / \mathrm{SiO}_{2}-\mathrm{OSi}(\mathrm{Me})_{2} \mathrm{Bu} & \mathrm{Ru} / \mathrm{SiO}_{2}-\mathrm{OH} \\ \mathrm{RuO}_{2}[\mathrm{~nm}]^{a} & 1.5 \pm 0.3 & 1.5 \pm 0.2 & 1.6 \pm 0.3 \\ \mathrm{Ru}(0)[\mathrm{nm}]^{b} & 1.3 \pm 0.4 & 1.3 \pm 0.3 & 1.4 \pm 0.3 \\ \text { Dispersion }^{c} & 0.75 & 0.75 & 0.73\end{array}$

${ }^{a}$ Particle size of the samples exposed to ambient air $\left(\mathrm{RuO}_{2}\right)$

${ }^{b}$ Calculated particle size of $\mathrm{Ru}(0)$ assuming bulk-like molar volume of RuNPs.

${ }^{c}$ Dispersion calculated based on the particle size of $\mathrm{Ru}(0)$. 
a)

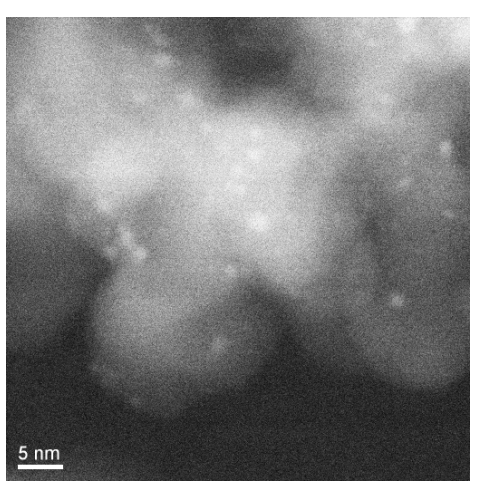

c)

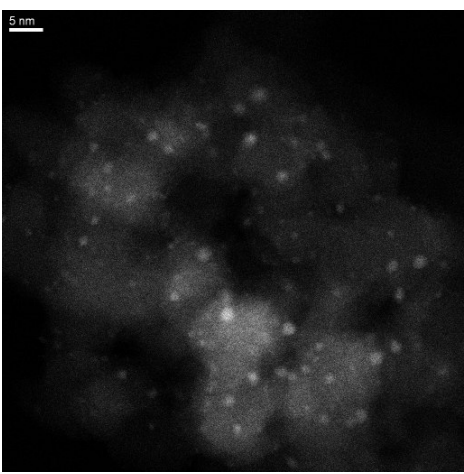

e)

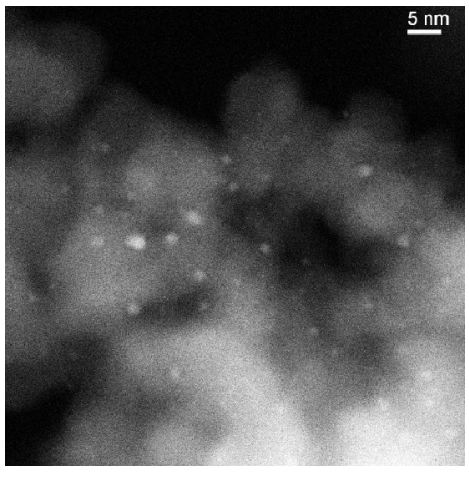

b)
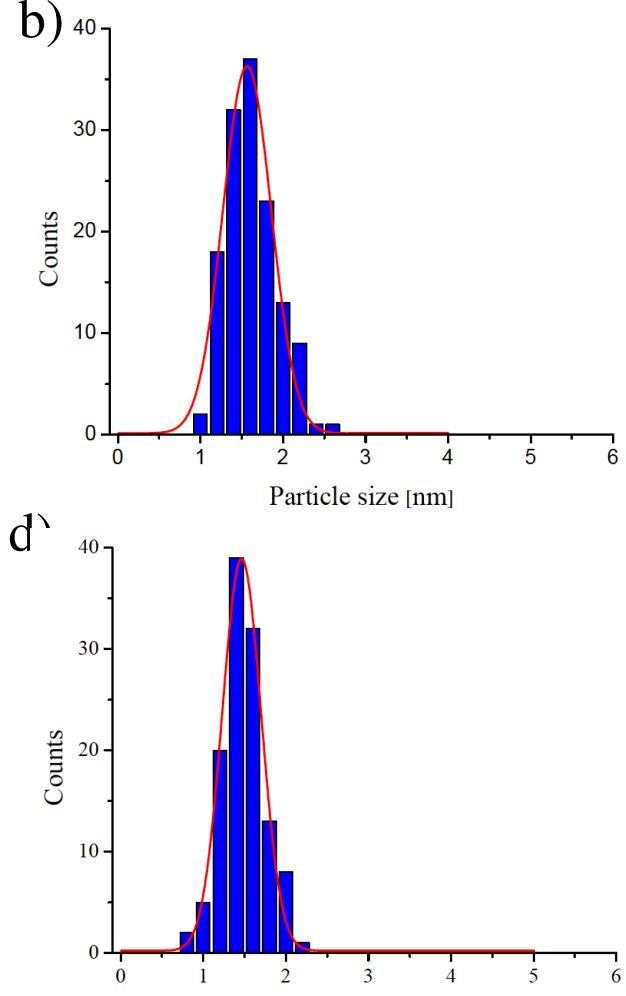

Particle size [nm]

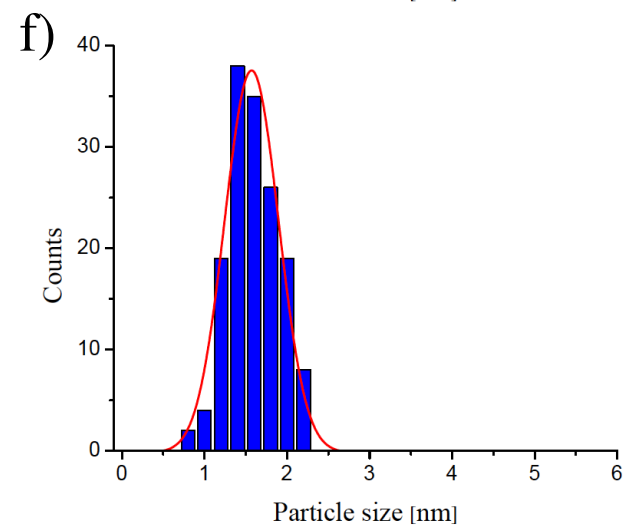

Figure 2. Respective HAADF-STEM and particle size distribution of $\mathrm{Ru} / \mathrm{SiO}_{2}$ $\mathrm{OSi}(\mathrm{Me})_{2} \mathrm{Me}$ : a) and b); $\mathrm{Ru} / \mathrm{SiO}_{2}-\mathrm{OSi}(\mathrm{Me})_{2} \mathrm{Bu}$ : c) and d); and $\mathrm{Ru} / \mathrm{SiO}_{2}-\mathrm{OH}$ : e) and f).

All catalysts were evaluated in WGS/methanation as follows: the supported $\mathrm{Ru}$ nanoparticles were loaded into a Plug Flow Reactor [27] and then reduced in pure $\mathrm{H}_{2}(50$ $\left.\mathrm{mL} \cdot \mathrm{min}^{-1}\right)$ at $400{ }^{\circ} \mathrm{C}\left(5{ }^{\circ} \mathrm{C} \cdot \mathrm{min}^{-1}\right)$ for $5 \mathrm{~h}$, followed by a pretreatment at the standard WGS/methanation conditions ( $7 \% \mathrm{CO}, 22 \% \mathrm{H}_{2} \mathrm{O}, 8.5 \% \mathrm{CO}_{2}, 37.5 \% \mathrm{H}_{2}$, and balance $\mathrm{Ar}$ ) 
with a flow rate of $75.4 \mathrm{~mL} \cdot \mathrm{min}^{-1}$ at $300{ }^{\circ} \mathrm{C}$ for $20 \mathrm{~h}$ [28]. After this pre-treatment, the temperature was lowered to reach conversion less than $10 \%$ in order to determine WGS/methanation rates and reaction orders under kinetic conditions $\left(275{ }^{\circ} \mathrm{C}\right.$ for $\mathrm{Ru} / \mathrm{SiO}_{2}-\mathrm{OH}$, and to $260{ }^{\circ} \mathrm{C}$ for RuNPs supported on passivated silica).

Table 2. Methanation kinetic study for supported RuNPs: rates, apparent activation energies and reaction orders in $\mathrm{H}_{2}, \mathrm{CO}, \mathrm{H}_{2} \mathrm{O}$ and $\mathrm{CO}_{2}$.

Materials Rate $\left(10^{-2}\right.$ mole $\mathrm{CH}_{4}$ $(\text { mole } \mathrm{Ru})^{-1} \mathrm{~s}^{-1} a$

TOF $\left(10^{-2}\right.$ mole $\mathrm{CH}_{4}$ $\left.\left(\text { mole } \mathrm{Ru}_{\text {surf. }}\right)^{-1} \mathrm{~s}^{-1}\right)^{b}$ $\mathrm{E}_{\text {app }}(\mathrm{kJ} / \mathrm{mol})$ $\mathrm{H}_{2}$

Reaction $\quad \mathrm{CO}$ orders $^{c}$ $\mathrm{Ru} / \mathrm{SiO}_{2}-\mathrm{OSi}(\mathrm{Me})_{2} \mathrm{M}$ $R u / S i$ 7.0

1.4

$$
78 \pm 1
$$

$$
1.19 \pm 0.02
$$$$
-0.44 \pm 0.04
$$$$
0.03 \pm 0.01
$$$$
0.07 \pm 0.02
$$

$$
70 \pm 2
$$$$
1.23 \pm 0.03
$$$$
-0.47 \pm 0.04
$$$$
0.01 \pm 0.02
$$$$
0.01 \pm 0.01
$$

$$
121 \pm 3
$$

$$
0.89 \pm 0.04
$$$$
-0.53 \pm 0.07
$$$$
-0.20 \pm 0.06
$$

$$
0.08 \pm 0.02
$$

${ }^{a}$ Reported rate with respect to methane at $300{ }^{\circ} \mathrm{C}, 7 \% \mathrm{CO}, 22 \% \mathrm{H}_{2} \mathrm{O}, 8.5 \% \mathrm{CO}_{2}, 37.5 \%$ $\mathrm{H}_{2}$.

${ }^{b}$ TOF with respect to methane reported at $300^{\circ} \mathrm{C}\left(\mathrm{s}^{-1}\right)$ and calculated per mol of surface $\mathrm{Ru}$ atom by taking into account the fresh catalyst dispersion obtained from HAADFSTEM (Table 1.)

${ }^{c}$ Orders of the reaction were measured at $260^{\circ} \mathrm{C}$ for $\mathrm{Ru} / \mathrm{SiO}_{2}-\mathrm{OSi}(\mathrm{Me})_{2} \mathrm{Me}$ and $\mathrm{Ru} / \mathrm{SiO}_{2}-$ $\mathrm{OSi}(\mathrm{Me})_{2} \mathrm{Bu}$ and at $275^{\circ} \mathrm{C}$ for $\mathrm{Ru} / \mathrm{SiO}_{2}-\mathrm{OH}$.

Under these reaction conditions, both methanation and WGS reactions are favored, but all supported RuNPs shows very high selectivity (> 90\%) towards methanation, which is consistent with the ease of $\mathrm{CO}$ dissociation on $\mathrm{Ru}$ surface [29]. Post-catalytic TEM characterization showed that the mean diameter of supported RuNPs does not change during the kinetic test (Figure S7, Table S1), and X-ray photoelectron spectroscopy after reduction or post reaction indicates that RuNPs remains metallic under reaction conditions (Figure S9, S10, S11, Table S2.), similarly to what was previously observed by 
the groups of Robert J. Davies [30], and Alexis T. Bell [31], under reducing conditions in the presence of water. It is noteworthy that $>70 \%$ of the passivating group remains on $\mathrm{Ru} / \mathrm{SiO}_{2}-\mathrm{OSi}(\mathrm{Me})_{2} \mathbf{B u}$ and $\mathrm{Ru} / \mathrm{SiO}_{2}-\mathrm{OSi}(\mathrm{Me})_{2} \mathrm{Me}$ respectively after $20 \mathrm{~h}$ at $270{ }^{\circ} \mathrm{C}$ under a flow of $\mathrm{H} 2, \mathrm{CO}, \mathrm{CO} 2$ and $\mathrm{H} 2 \mathrm{O}$ (Figure S8). It is noteworthy that RuNPs supported on passivated silica present much higher rates (per mole of $\mathrm{Ru}$ ) or turnover frequencies (per

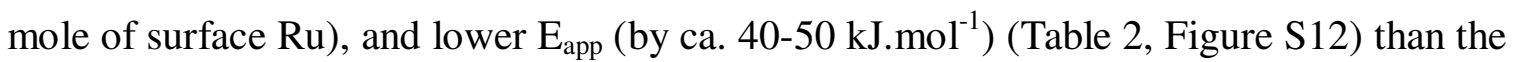
corresponding particles supported on silica. ${ }^{\ddagger}$ Measuring reaction orders for $\mathrm{H}_{2}, \mathrm{CO}, \mathrm{H}_{2} \mathrm{O}$ and $\mathrm{CO}_{2}$ shows however only minor differences between the catalysts, indicating similar reaction pathway and active sites. Nonetheless, it also suggests that the the energetics of some of the elementary steps involved in the reaction are perturbed by the presence of passivating groups, thus leading to a difference in the reaction rate. The reaction orders with respect to $\mathrm{H}_{2}$ (Table 2, Figure $\mathrm{S} 13$ ) are 0.89 (for non-passivated), 1.19 and 1.23 for passivated supports $\left(\mathrm{SiO}_{2}-\mathrm{OSi}(\mathrm{Me})_{2} \mathrm{Me}\right.$ and $\mathrm{SiO}_{2}-\mathrm{OSi}(\mathrm{Me})_{2} \mathbf{B u}$ respectively), indicating that hydrogen pressure has a slightly more positive effect on methanation rate on passivated samples. Interestingly, for RuNPs on passivated supports, the order of the reaction with respect to $\mathrm{H}_{2}$ is higher than one, which can be explained by the fact, that $\mathrm{H}_{2}$ and CO compete for the same adsorption sites [33]. The orders with respect to CO (Table 2, Figure S14) are negative and similar (ca. -0.5) for all catalysts, which is in agreement with an inhibiting effect of $\mathrm{CO}$ on methanation rates [34]. For $\mathrm{H}_{2} \mathrm{O}$ (Table 2, Figure S15), the reaction order is close to 0 , showing that water does not inhibit the methanation

\# The reaction rate per mole of surface $\mathrm{Ru}$ for RuNPs supported on silica is consistent with the previosuly reported activity of RuNPs on $\mathrm{SiO}_{2}$ towards methanation, see: I. G. Bajusz, J. G. Goodwin Jr. J. Catal, 169 (1997) 157. 
reaction. ${ }^{\S}$ Note the slightly negative value for the silica supported catalyst, indicating its small inhibitory effect, probably because of slower desorption of $\mathrm{H}_{2} \mathrm{O}$ from the more hydrophilic silica surface. The $\mathrm{CO}_{2}$ order for all the catalyst is 0 , since it is not involved in methanation reaction (Figure S16).**

While the study of the reaction orders did not reveal any significant difference between the catalysts, chemisorption studies outlined major differences. Indeed, the $\mathrm{H}_{2}$ and $\mathrm{CO}$ chemisorption differ particularly from passivated to non-passivated silica supported RuNPs (Table 3, Figure S17, S18).

Table 3. $\mathrm{H}_{2}$ and CO chemisorption for supported RuNPs. ${ }^{a}$

\begin{tabular}{cccc}
\hline Materials & $\mathrm{Ru} / \mathrm{SiO}_{2}-\mathrm{OSi}(\mathrm{Me})_{2} \mathrm{Me}$ & $\mathrm{Ru} / \mathrm{SiO}_{2}-\mathrm{OSi}(\mathrm{Me})_{2} \mathrm{Bu}$ & $\mathrm{Ru} / \mathrm{SiO}_{2}-\mathrm{OH}$ \\
$\mathrm{Q}_{\max }\left(\mu \mathrm{mol}_{\left.\mathrm{H} 2 \cdot \mathrm{g}_{\mathrm{cat}}{ }^{-1}\right)}\right.$ & 54 & 49 & 54 \\
$\mathrm{Q}_{\max }\left(\mu \mathrm{mol}_{\left.\mathrm{CO} \cdot \mathrm{g}_{\mathrm{cat}}{ }^{1}\right)}\right.$ & 90 & 109 & 144 \\
Dispersion $\left(\mathrm{H}_{2}\right)^{b}$ & 0.71 & 0.64 & 0.71 \\
\hline
\end{tabular}

${ }^{a}$ All samples are treated at $350^{\circ} \mathrm{C}\left(10^{-6}\right.$ mbar $)$ prior the chemisorption measurement, which is performed at $25^{\circ} \mathrm{C}$. The chemisorption data are fitted with a dual dissociative $\left(\mathrm{H}_{2}\right)$ and non dissociative $(\mathrm{CO})$ adsorption Langmuir model to estimate the quantity of adsorbed gas at saturation $\left(\mathrm{Q}_{\max }\right)$ [32].

${ }^{b}$ Calculated assuming $2 \mathrm{H} / \mathrm{Ru}_{\text {surf }}$ adsorption [26].

On the one hand, the maximum quantity of $\mathrm{H}_{2}$ measured $\left(\mathrm{Q}_{\max }\right)$ is very similar for all catalysts (49-54 $\left.\mu \mathrm{molH}_{2} \cdot \mathrm{g}_{\mathrm{cat}}{ }^{-1}\right)$ and are in line with the adsorption of ca. $2 \mathrm{H} / \mathrm{Ru}$ (obtained comparing HAADF-STEM results) as found previously on silica-supported RuNPs [26]

\footnotetext{
${ }^{\S}$ Based on the $\mathrm{H}_{2} \mathrm{O}$ adsorption experiment (Figure S24) the calculated amount of $\mathrm{H}_{2} \mathrm{O}$ monolayers at $260^{\circ} \mathrm{C}$ is $0.01 \mathrm{ML}$ for $\mathrm{SiO}_{2}-\mathrm{OH}$ and $0.004 \mathrm{ML}$ for $\mathrm{SiO}_{2}-\mathrm{OSi}(\mathrm{Me})_{2} \mathrm{Me}$.

** Additionally, as shown by Panagiotopoulou et al. [35] who studied $\mathrm{CO}$ methanation reaction over $\mathrm{Ru} / \mathrm{Al}_{2} \mathrm{O}_{3}$ at $250^{\circ} \mathrm{C}$ with co-feeded $\mathrm{CO}_{2}$ and $\mathrm{H}_{2} \mathrm{O}$, the rate of $\mathrm{CO}$ methanation is higher than the rate of $\mathrm{CO}_{2}$ methanation by a factor of 14 . The partial pressure of $\mathrm{CO}_{2}$ used in abovementioned study (15\%) was 15 times higher than the partial pressure of $\mathrm{CO}(1 \%)$. Thus, even in excess of $\mathrm{CO}_{2}$, the rate of methanation was lower by an order of magnitude for $\mathrm{CO}_{2}$. In our kinetic measurement the $\mathrm{CO}_{2} / \mathrm{CO}$ ratio was 1.25. Hence, we believe that the extent of $\mathrm{CO}_{2}$ methanation was significantly lower than the one for $\mathrm{CO}$ methanation.
} 
In addition, the similar values of $\mathrm{Q}_{\max }$ obtained by $\mathrm{H}_{2}$-chemisorption indicate similar accessibility of Ru surface atoms in all samples. Since the dispersions evaluated by both HAADF-STEM and $\mathrm{H}_{2}$-chemisorption are very similar (Table 1, Table 3), the number of subnanometer particles is probably small and does not contribute significantly to the observed rate difference between passivated and unpassivated silica surface.[35] On the other hand, the $\mathrm{CO}$ adsorption properties vary greatly, $\mathrm{Ru} / \mathrm{SiO}_{2}-\mathrm{OSi}(\mathrm{Me})_{2} \mathrm{Me}$ and $\mathrm{Ru} / \mathrm{SiO}_{2}-\mathrm{OSi}(\mathrm{Me})_{2} \mathrm{Bu}$ adsorbing $37 \%$ and $24 \%$ less $\mathrm{CO}$ than on the non-passivated system, $\mathrm{Ru} / \mathrm{SiO}_{2}-\mathrm{OH}$. In addition, the linear fitting of the data points from the Henry Law regime of CO isotherm (Figure S19) shows that the shape of the isotherm varies for RuNPs on passivated and nonpassivated $\mathrm{SiO}_{2}$. The higher slope for silica-supported RuNPs $(a=1.42)$ compared to RuNPs supported on passivated silica ( 0.64 and 0.51 for $\mathrm{Ru} / \mathrm{SiO}_{2}-\mathrm{OSi}(\mathrm{Me})_{2} \mathrm{Bu}$ and $\mathrm{Ru} / \mathrm{SiO}_{2}-\mathrm{OSi}(\mathrm{Me})_{2} \mathrm{Me}$ respectively) indicates that $\mathrm{CO}$ binds more strongly on RuNPs supported on the former, consistent with a higher affinity of CO. The IR spectra of supported RuNPs contacted with an excess of CO are consistent with this observation, with a decrease of the intensity of the CO bands by $41 \%$ and $38 \%$ for $\mathrm{Ru} / \mathrm{SiO}_{2}-\mathrm{OSi}(\mathrm{Me})_{2} \mathrm{Me}$ and $\mathrm{Ru} / \mathrm{SiO}_{2}-\mathrm{OSi}(\mathrm{Me})_{2} \mathrm{Bu}$ compared to $\mathrm{Ru} / \mathrm{SiO}_{2}-\mathrm{OH} .{ }^{\dagger \dagger}$ However the nature of the $\mathrm{CO}$ adsorbed species does not seem to be dramatically perturbed as the CO bands are similar for all samples (Figure S20). Furthermore, the CO-TPD (Temperature Programmed Desorption) study of catalysts, previously exposed with CO, barely shows any evolution of $\mathrm{CO}$ (Figure S21), while significant amount of $\mathrm{CO}_{2}$ is observed, presumably arising from Boudouard reaction (CO disproportionation) or WGS (with residual adsorbed water). The main $\mathrm{CO}_{2}$ peak is observed at $480^{\circ} \mathrm{C}, 485^{\circ} \mathrm{C}$ and

${ }^{+t}$ IR spectra were normalized with respect to siloxane bridge ( $\mathrm{Si}-\mathrm{O}-\mathrm{Si}$ ) region of the IR spectra. 
$560^{\circ} \mathrm{C}$ for $\mathrm{Ru} / \mathrm{SiO}_{2}-\mathrm{OSi}(\mathrm{Me})_{2} \mathrm{Me}, \mathrm{Ru} / \mathrm{SiO}_{2}-\mathrm{OSi}(\mathrm{Me})_{2} \mathrm{Bu}$ and $\mathrm{Ru} / \mathrm{SiO}_{2}-\mathrm{OH}$, respectively (Figure S22), consistent with the easier product formation and/or desorption for Ru particles on passivated support. In addition, the amount of $\mathrm{CO}_{2}$ evolved during the $\mathrm{CO}-$ TPD experiment was significantly lower for RuNPs on passivated silica than on RuNPs supported on $\mathrm{SiO}_{2}$. For $\mathrm{Ru} / \mathrm{SiO}_{2}-\mathrm{OSi}(\mathrm{Me})_{2} \mathrm{Me}$ and $\mathrm{Ru} / \mathrm{SiO}_{2}-\mathrm{OSi}(\mathrm{Me})_{2} \mathbf{B u}$ the amount of $\mathrm{CO}_{2}$ evolved during CO-TPD was $28 \%$ and $23 \%$ lower on the non-passivated system, $\mathrm{Ru} / \mathrm{SiO}_{2}-\mathrm{OH}$, which is consistent with the CO chemisorption experiments (Table S3). However, while we have no direct evidence for it, the observed change of adsorption properties of supported RuNPs upon modification of the nanoparticle-support interaction (interface between the nanoparticle and the support) might be due to a change of the particle morphology (e.g. change of shape) or their electronic state.

\section{Conclusions}

The increase in methanation rate observed for RuNPs supported on passivated silica is likely arising from the lower adsorption affinity for $\mathrm{CO}$ on RuNPs in view of the inhibition of the reaction by CO (negative order). While the similar kinetic parameters for all catalysts indicate that the mechanism of the reaction remains unchanged for studied RuNPs, the observed difference of rates suggests that the energetics of some of the elementary steps are likely perturbed by the change of interface, i.e. the presence of the organosilane functionality. Overall, the observed change of adsorption properties and reactivity of supported RuNPs clearly results from the modification of the interface, and it could be due to a change of Ru particle morphology (shape) and/or their electronic state. We are currently further exploring this approach to tune the activity and selectivity 
of supported metal nanoparticles, where the interface between the particle and the support can play an important role.

\section{Acknowledgments}

We thank the Swiss National Foundation for founding (SNF project number 200021_134775/1 Controlled Surface Chemistry for Catalyst Design) and U.S. Department of Energy, Office of Basic Energy Sciences, Catalysis Science Grant No. DE-FG02-03ER15466. We are also grateful to Frank Krumeich and Cem Akatay for electron microscopy images, obtained on the ScopeM platform, as well as Dmitry Zemlyanov and Michael Detwiler for the XPS analysis.

\section{$\underline{\text { References }}$}

[1] S. Chu, A. Majumdar, Nature, 488 (2012) 294.

[2] BP Statistical Review of World Energy (2013).

[3] National Research Council, Advancing the Science of Climate Change, The National Academies Press (2010).

[4] G. Olah, Angew Chem. Int. Ed. 52 (2013) 104.

[5] R. Schlögl, Angew Chem. Int. Ed. 50 (2011) 6424.

[6] G. A. Somorjai, L. Yimin, Introduction to Surface Chemistry and Catalysis (1994) Wiley.

[7] F. Raimondi, G. Scherer, R. Kötz,, A. Wokaun, Angew Chem. Int. Ed. 44 (2005) 2190.

[8] K.P. De Jong, Synthesis of Solid Catalysts (2009) Wiley 
[9] G. Prieto, J. Zecevic, H. Friedrich, K.P. De Jong, P. E. De Jongh, Nature Materials, $12(2013) 34$.

[10] J. P. Den Breejen, P. B. Radstake, G.L. Bezemer, J. H. Bitter, V. Froseth, A.

Holmen, K. P. De Jong, J. Am. Chem. Soc. 131 (2009) 7197.

[11] M. Cargnello, V. V. T. Doan-Nguyen, T. R. Gordon, R. E. Diaz, E. A. Stach, R. J.

Gorte, P. Fornasiero, C. B. Murray, Science 341 (2013) 771.

[12] R. L. Baker, G. Kennedy, M. van Spronsen, A. Hervier, C. Xiaojun.; C. Shiyou.

L.W. Wang, G. A. Somorjai, J. Am. Chem. Soc. 134 (2012) 14208.

[13] J. A. Farmer, C. T. Campbell, Science, 329 (2010) 933.

[14] G. Chen, Y. Zhao, G. Fu, P. N. Duchesne, L. Gu, Y. Zheng, X. Weng, M. Chen, P. Zhang, C. Pao, J-F. Lee, N. Zheng, Science, 2 (2014) 495.

[15] M. Ramakrishna Prasad, M. Hamdy, G. Mul, E. Bouwman, E. Drent, J. Catal. 260 (2008) 288.

[16] D. Ruddy, T. D. Tilley, Chem. Commun, 32 (2007) 3350.

[17] T. Tatsumi, K. A. Koyano, N. Igarashi, Chem. Commun. 3 (1998) 325.

[18] M. Ojeda, F. Perez-Alonso, P. Terreros, S. Rojas, T. Herranz, M. Granados, J. L. Fierro, Langmuir 22 (2006) 3131.

[19] A. Quintanilla, J. J. W. Bakker, M. T. Kreutzer, J. A. Moulijn, F. Kapteijn, J. Catal. 257 (2008) 55.

[20] D. Baudouin, K. C. Szeto, P. Laurent, A. de Mallmann, B. Fenet, B. L. Veyre, U.

Rodemerck, C. Copéret, C. Thieuleux, J. Am. Chem. Soc. 134 (2012) 20624.

[21] L. Shi, J. Chen, K. Fang, Y. Sun, Fuel, 87 (2008) 521.

[22] L. Jia, L. Jia, D. Li, B. Hou, J. Wang, Y. Sun, J. Solid State Chem. 184 (2011) 488. 
[23] D. Gajan, K. Guillois, P. Delichère, J-M. Basset, J-P. Candy, V. Caps, C. Copéret, A. Lesage, L. Emsley, J. Am. Chem. Soc. 131 (2009) 14667.

[24] F. Rascon, R. Wischert, C. Copéret, Chem. Sci. 2 (2011) 1449.

[25] R. Anwander, I. Nagl, M. Widenmeyer, G. Engelhardt, O. Groeger, C. Palm, T.

Röser, J. Phys. Chem. B. 104 (2000) 3532.

[26] R. Berthoud, P. Délichère, D. Gajan, W. Lukens, K. Pelzer, J-M. Basset, J-P. Candy, C. Copéret, J. Catal. 260 (2008) 387.

[27] L. Bollmann, J. L. Ratts, A. J. Joshi, W. D. Williams, J. Pazmino, Y. V. Joshi, J. T. Miller, A. J. Kropf, W. N. Delgass, F. H. Ribeiro, J. Catal. 257 (2008) 43.

[28] W. D. Williams, M. Shekhar, M. Lee, V. Kispersky, W. N. Delgass, F. H. Ribeiro, S. M. Kim, E. A. Stach, J. T. Miller, L. F. Allard, J. Am. Chem. Soc. 132 (2010) 14018.

[29] B. T. Loveless, C. Buda, M. Neurock, E. Iglesia, J. Am. Chem. Soc. 135 (2013) 6107.

[30] W. C Ketchie, E. P. Maris, R. J. Davis, J. Chem. Mater. 19 (2007) 3406.

[31] J. G. Ekerdt, A. T. Bell, J. Catal. 58 (1979) 170.

[32] J. E. Low, A. Foelske-Schmitz, F. Krumeich, M. Wörle, D. Baudouin, F. Rascón, C. Copéret, Dalton Trans. 42 (2013) 12620.

[33] A. I. Fisher, A. T. Bell, J. Catal. 162 (1996) 54.

[34] J. Alstrup, J. Catal. 151 (1995) 216.

[35] P. Panagiotopoulou, D. Kondarides, X. Verykios, Appl. Catal. A. 344 (2008) 45. 


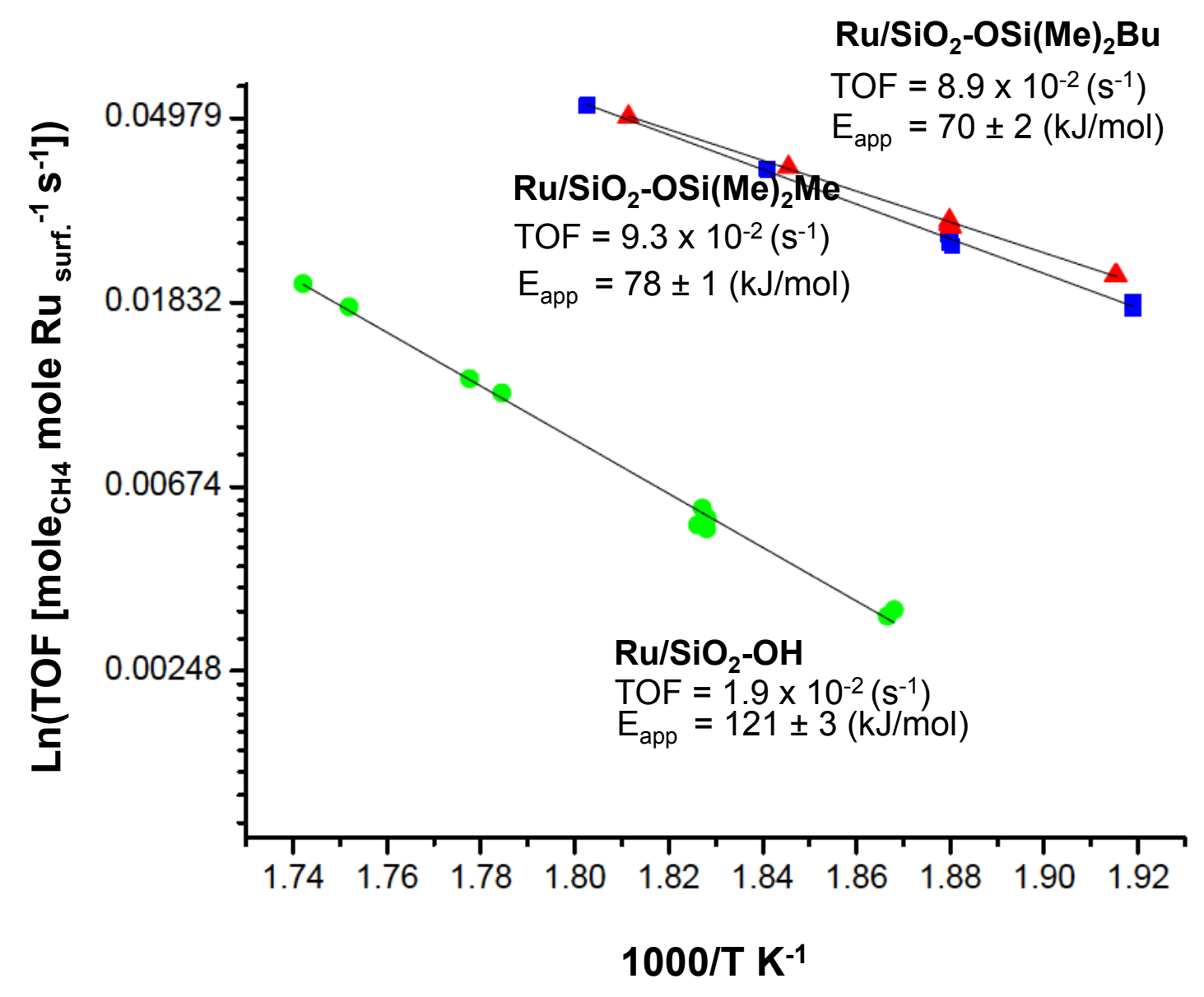

